\title{
PENGARUH PENGALAMAN DAN KETERIKATAN EMOSIONAL PADA MERK TERHADAP LOYALITAS KONSUMEN
}

\author{
Badri Munir Sukoco (badri@feb.unair.ac.id) \\ Reza Aditya Hartawan \\ Fakultas Ekonomi dan Bisnis, Universitas Airlangga
}

\begin{abstract}
Having consumers who repeatedly purchase the brand is marketers' desire. This study develops arguments that repeated purchase determined by the experience of customers with the brand as well as how strong their emotional attachment toward the brand. This study further argues that the effects of consumers' brand experience and emotional attachment to brand are stronger when they are highly involved with the products. Onehundred eighty respondents participated in this study on 6 different famous brands. The results reveal that the effect of brand experience on repurchase intention is mediated by emotional attachment to brand. When consumers highly involve to the product, the effect of brand experience on repurchase intention becomes stronger. Managerial and academic implications are also presented.
\end{abstract}

Keywords: Brand Experience, Emotional Attachment, Product Involvement, and Repurchase Intention

\section{LATAR BELAKANG}

Pelanggan yang melakukan pembelian secara berulang pada merk yang dipasarkan merupakan impian bagi pemasar, mengingat loyalitas yang mereka lakukan akan secara konsisten berkontribusi pada penerimaan maupun laba yang dihasilkan perusahaan (Reichheld, 1996). Agar konsumen loyal, perusahaan menggunakan program-program loyalitas, seperti memberikan hadiah ke pelanggan pada momen tertentu (misal: O'Brien dan Jones, 1995) atau mengunci pelanggan melalui kompatibilitas produk, seperti hanya toner asli yang bisa digunakan untuk printer tertentu (misal: Buschken, 2004).

Namun, sebagian besar peneliti berpendapat bahwa pembelian kembali akan semakin baik bilamana pelanggan memiliki perasaan positif yang sangat kuat terhadap merk (misal: Dick dan Basu, 1994), melibatkan kondisi psikologis yang mengikat pelanggan dengan merk (Kotler dan Keller, 2011) dan menguatkan komitmen untuk melakukan pembelian secara berulang (Oliver, 1999). Penerimaan dan laba yang dihasilkan dari pembelian berulang karena pelanggan terikat secara emosional akan lebih stabil (Grisaffe dan Nguyen, 2011) dan mereka siap untuk mengorbankan keuangannya guna mengonsumsi merk tersebut (Oliver, 1999). Hubungan ini dikenal dengan nama emotional attachment to brands keterikatan emosional pelanggan pada merk (Thomson, Maclnnis, dan Park, 2005).

Namun, Belk (1988) berargumen bahwa keterikatan emosional tersebut tidak akan ada bilamana pelanggan tersebut tidak memiliki pengalaman yang intens dalam mengonsumsi merk tersebut. Peneliti sebelumnya berpendapat bahwa konsumen memiliki pengalaman dengan suatu merk ketika mereka sedang mencari produk yang tepat, melakukan pembelian, dan menggunakannya (Arnould, Price, dan Zinkhan, 2002; Brakus, Schmitt, dan Zhang, 2008), dikenal dengan brand experience - pengalaman merk (Brakus, Schmitt, dan Zarantonello, 2009). Bilamana pengalaman yang mereka miliki positif, diprediksikan konsumen akan dengan senang hati melakukan pembelian kembali merk tersebut.

Brand experience menekankan pada pengalaman yang dialami pelanggan secara subyektif (Brakus dkk., 2009), sedangkan emotional attachment to brands menjelaskan keterikatan emosional pelanggan pada merk yang dikonsumsinya. Hingga saat ini, belum 
terdapat penelitian yang menggabungkan dua konsep tersebut dalam sebuah model yang lebih komprehensif guna menjelaskan loyalitas konsumen pada suatu merk.

Penelitian ini juga menyempurnakan penelitian terdahulu yang menafikan perbedaan pengalaman (Brakus dkk., 2009) maupun keterikatan emosional (Thomson dkk., 2005) pada produk yang berbeda. Mengadopsi konsep product involvement - keterlibatan pada produk (Zaichkowsky, 1985), peneliti berargumen bahwa perbedaan motivasi konsumen dalam mencari, mengolah, dan memutuskan pembelian menjadikan pengaruh pengalaman dan keterikatan emosional mereka terhadap loyalitas berbeda. Diharapkan kedua hal baru tersebut dapat memberikan perspektif baru pada literatur pemasaran sekaligus kemanfaatan baru bagi pemasar dalam meningkatkan level pembelian kembali oleh pelanggan yang mereka miliki.

\section{TINJAUAN PUSTAKA}

Pengalaman Merk

Konsumen memiliki pengalaman dengan merk tertentu ketika mereka ter-ekspos pada beberapa stimuli yang terkait dengan merk tersebut, misalnya warna (misal: Meyers-Levy dan Peracchio, 1995), bentuk (Veryzer dan Hutchinson, 1998), jenis huruf yang digunakan (Mandel dan Johnson, 2002), slogan atau maskot (Keller, 1987) maupun ketika mereka sedang membeli maupun mengkonsumsinya. Hal tersebut yang mendasari Brakus dkk. (2009) mengajukan konsep brand experience (pengalaman merk) dan mendefinisikannya sebagai tanggapan subyektif (sensasi, perasaan, dan pikiran) dan perilaku konsumen yang ditimbulkan oleh stimuli yang terkait dengan suatu merk berupa desain dan identitas (nama, logo, kemasan dan komunikasi (brosur, websites), maupun lingkungannya (toko yang menjual). Lebih lanjut, Brakus dkk. (2009) mengoperasionalkan konsep tersebut menjadi 4 dimensi, yakni sensory (indrawi), affective (afektif), behavioral (perilaku), dan intellectual (intelektual).

\section{Keterikatan Emosional pada Merk}

Attachment (keterikatan) merupakan suatu kondisi emosional pada hubungan khusus antara seseorang dan obyek tertentu (Bowlby, 1979, 1980). Keterikatan memiliki tingkatan yang bervariasi, dimana keteriukatan yang tinggi diasosiasikan dengan perasaan yang kuat dari connection (koneksi), affection (afeksi), love (cinta), dan passion (gairah) (misal: Aron dan Westbay, 1996). Hasrat untuk memiliki keterikatan emosional pada suatu obyek merupakan kebutuhan dasar masuia (Ainsworth, Blehar, Waters, dan Wall, 1978; Bowlby, 1980), yang dimulai ketika bayi terikat pada ibunya (Bowlby, 1979, 1980) dan berlanjut hingga mereka dewasa yang terikat secara emosional pada pasangannya (Hazan dan Shaver, 1994) maupun sahabatnya (Weiss, 1988). Berdasarkan teori tersebut, Thomson dkk. (2005) mengembangkan konsep emotional attachment to brands dan mendefinisikannya sebagai keterikatan emosional antara konsumen yang dikarakteristikkan dengan perasaan yang mendalam mengenai koneksi, afeksi, dan gairah pada merk tertentu yang dikonsumsinya.

\section{Keterlibatan pada Produk}

Involvement (keterlibatan) berdasarkan kebutuhan, nilai, dan ketertarikan yang memotivasi konsumen pada suatu obyek (Zaichkowsky, 1985). Lebih lanjut, Zaichkowsky (1985) menyatakan bahwa keterlibatan tergantung pada tingkat ke-penting-an dan relevansi personal konsumen pada suatu obyek, dan dalam penelitian ini obyek tersebut adalah produk. Definisi lain ditawarkan oleh Park dan Mittal (1985) yang menyatakan bahwa keterlibatan merupakan suatu kesiapan mental konsumen dalam berpikir guna mengambil keputusan dan tindakan mereka yang berkaitan dengan suatu produk. Penelitian ini mengadopsi kedua definisi yang telah diterima oleh umum tersebut dan mendefinisikan 
keterlibatan sebagai tingkat ke-penting-an dan relevansi personal konsumen pada suatu produk yang melibatkan pemikiran guna mengambil keputusan dan tindakan.

\section{PENGEMBANGAN HIPOTESA}

Interaksi yang terjadi secara berulang akan memperkaya pengalaman konsumen dengan suatu merk, yang mana dari waktu ke waktu akan menguatkan keterikatan emosional mereka pada merk tersebut (Baldwin, Keelan, Fehr, Enns, dan Koh-Rangarajoo, 1996). Hal tersebut juga konsisten dengan pendapat dari Belk (1988) bahwa keterikatan konsumen secara emosional akan dibangun ketika mereka telah mengalami atau berinteraksi secara langsung dengan merk tersebut. Sehingga dapat dikemukakan bahwa pengalaman dengan suatu merk merupakan prasyarat sebelum konsumen memiliki keterlibatan emosional pada suatu merk.

Selain meningkatkan keterikatan emosional, pengalaman dengan merk yang positif juga berpengaruh secara positif terhadap loyalitas mereka pada suatu merk (Oliver, 1997; Reicheld, 1996). Hal ini juga ditunjukkan dengan hasil studi yang dilakukan oleh Brakus dkk. (2009) yang menunjukkan bahwa pengalaman dengan suatu merk berpengaruh secara positif dan signifikan terhadap loyalitas konsumen. Berdasarkan hal tersebut, dua hipotesa berikut diajukan:

H1: Pengalaman konsumen dengan merk berpengaruh secara positif terhadap keterikatan emosional mereka pada merk tersebut.

H2: Pengalaman konsumen dengan merk berpengaruh secara positif terhadap niat mereka untuk melakukan pembelian kembali merk tersebut.

Seperti yang diungkapkan oleh Bowlby (1980), terikat secara emosional akan mendorong seseorang untuk selalu dekat dengan obyek yang dimaksud. Tentunya terikat secara emosional dengan suatu merk akan mendorong seseorang untuk selalu dekat dengannya melalui pembelian yang dilakukan secara berulang. Keterikatan emosional juga dapat memprediksi komitmen seseorang dalam jangka panjang (Drigotas dan Rusbult, 1992) dan memiliki keinginan untuk menjaga hubungan yang telah ada meskipun banyak kendala yang menghadang (van Lange, Rusbult, Drigotas, dan Arriaga, 1997). Dalam konteks pemasaran, komitmen tersebut diwujudkan melalui kesediaan konsumen untuk melakukan pembelian secara berulang pada merk yang dimaksud. Selain itu, komitmen tersebut juga diwujudkan melalui kesediaan konsumen untuk melakukan pengorbanan (dalam hal ini keuangan) agar hubungan yang ada tetap terjalin dengan membelinya lagi dan lagi (Thomson dkk., 2005). Untuk itu, hipotesa berikut diajukan:

H3: Keterikatan emosional konsumen pada merk berpengaruh positif terhadap niat mereka untuk melakukan pembelian kembali merk tersebut.

Tingkat keterlibatan yang berbeda akan membedakan tingkat pencarian, pemikiran, maupun tindakan yang akan dilakukan oleh konsumen dalam mengkonsumsi suatu produk (Park dan Mittal, 1985; Zaichkowsky, 1985). Mengingat pengalaman suatu merk melibatkan pengalaman subyektif dan perilaku seorang konsumen (Brakus dkk., 2009), tentunya tingkat keterlibatan yang tinggi pada suatu produk akan memperkuat efek dari pengalaman merk terhadap niat konsumen untuk membeli kembali merk tersebut.

Hal yang sama juga berlaku pada keterikatan emosional konsumen pada suatu merk. Tingkat keterlibatan yang tinggi pada suatu menjadikan perasaan yang dimilikinya akan semakin dalam terhadap suatu produk (Thomson dkk., 2005), mengingat tingkat pencarian, pemikiran, dan tindakan yang mereka lakukan lebih tinggi dibandingkan bila mereka memiliki keterlibatan yang rendah (Park dan Mittal, 1985; Zaichkowsky, 1985). Hal inilah yang 
menjadikan pengaruh positif keterikatan emosional konsumen pada loyalitas akan semakin menguat bila mereka memiliki tingkat keterlibatan yang tinggi pada suatu produk. Maka,

H4: Pengaruh positif pengalaman konsumen dengan merk terhadap niat pembelian kembali akan semakin kuat bilamana mereka memiliki keterlibatan tinggi terhadap produk.

H5: Pengaruh positif keterikatan emosional konsumen pada merk terhadap niat pembelian kembali akan semakin kuat bilamana mereka memiliki keterlibatan tinggi terhadap produk.

\section{METODOLOGI PENELITIAN}

Penelitian ini menggunakan item dari beberapa sumber (detail pada Tabel 1). Untuk mengukur pengalaman merk, digunakan 12 item yang dikembangkan oleh Brakus dkk. (2009) dengan menggunakan 7 titik skala Likert. Sedangkan keterikatan emosional pada merk menggunakan item yang dikembangkan oleh Thomson akk. (2005) sebanyak 10 item dan diukur menggunakan 5 titik skala Likert. Adapun niat untuk membeli kembali diadopsi menggunakan item yang dikembangkan oleh Wu dan Sukoco (2010) menggunakan 6 titik skala Likert. Sedangkan tingkat keterlibatan konsumen pada produk menggunakan 6 item yang dikembangkan oleh Zaichkowsky (1985) menggunakan 5 titik semantic differential items.

Feldman dan Lynch (1988) memperhatikan bahwa responden dapat menggunakan jawaban yang diambil dari pertanyaan survei dari bagian sebelumnya sebagai masukan untuk menanggapi pertanyaan selanjutnya. Guna mengurangi efek self-generated validity, peneliti mengikuti prosedur Podsakoff, Mackenzie, Lee, dan Podsakoff (2003) melalui balancing order, yakni mengurutkan pertanyaan tidak secara berurutan (misalnya, coconsumption dan co-production diletakkan di awal, diikuti oleh modal sosial, kemudian nilai informasi dan social). Selain itu, peneliti juga mempresentasikan pertanyan dengan respon yang berbeda-beda (yaitu 5, 6, dan 7 skala Likert).

Penelitian ini menggunakan teknik purposive random sampling, dengan menyasar mahasiswa S1 Manajemen Fakultas Ekonomi dan Bisnis Universitas Airlangga yang telah menggunakan produk yang dijadikan obyek penelitian. Terdapat 3 tahapan dalam penelitian ini. Pertama, peneliti menentukan produk apa yang menurut konsumen mereka memiliki tingkat keterlibatan yang berbeda, baik yang tinggi maupun yang rendah. Menggunakan item yang dikembangkan oleh Beatty dan Talpade (1994), dari 20 responden yang berpartisipasi didapatkan bahwa konsumen memiliki keterlibatan tinggi pada handphone dan keterlibatan yang rendah pada snack. Kedua, dua kategori tersebut dijadikan dasar untuk mencari merk yang akan digunakan berdasarkan data Top Brand 2011 yang dikeluarkan oleh Majalah SWA. Masing-masing kategori mendapatkan 3 merk, untuk handphone adalah Blackberry, Nokia, dan Sony-Ericsson, sedangkan snack adalah Kacang Garuda, Wafer Tanggo, dan Biskuit Roma. Ketiga, dilakukan pre-test terhadap 30 responden dan hasilnya menunjukkan item yang akan digunakan sesuai dengan yang diharapkan. Keempat, survei utama dilakukan terhadap 180 responden.

Responden pria dan wanita memiliki proporsi yang seimbang (masing-masing 90 orang). Sebagian besar responden hanya mampu membelanjakan uangnya kurang dari 1 juta rupiah per bulan (82,8\%), sisanya memiliki kemampuan membelanjakan diatas jumlah tersebut. Sepertiga hingga duapertiga responden telah menggunakan merk yang dimaksud antara 1 hingga 3 tahun, sedangkan Nokia dan Sony-Ericsson yang telah terlebih dahulu dipasarkan di Indonesia memiliki proporsi sepertiga responden yang menggunakannya lebih dari 3 tahun. Sedangkan untuk snack, lebih dari 60\% responden telah mengkonsumsi merk yang digunakan dalam penelitian ini lebih dari 6 tahun. 


\section{ANALISA}

Peneliti menggunakan analisa faktor untuk mengetahui validitas dan reliabilitas dari itemitem yang digunakan (Tabel 1). Hasil analisa validitas menunjukkan bahwa semua faktor loading untuk masing-masing dimensi variabel penelitian mempunyai nilai di atas 0,500, dengan eigen-value di atas 1,000 serta percentage of variance diatas $60 \%$. Sedangkan analisa reliabilitas menunjukkan bahwa hampir semua dimensi memiliki Cronbach's Alpha lebih dari 0,700 (kecuali untuk dimensi intellectual dari pengalaman merk sebesar 0,621). Sedangkan item-to-total correlation memiliki nilai lebih dari 0,500.

Tabel 1 - Analisa Validitas dan Reliabilitas

\begin{tabular}{|c|c|c|c|c|c|c|}
\hline Kode & Pertanyaan & $\begin{array}{l}\text { Factor } \\
\text { Loading }\end{array}$ & $\begin{array}{l}\text { Eigen- } \\
\text { value }\end{array}$ & $\begin{array}{c}\% \text { of } \\
\text { Variance }\end{array}$ & $\begin{array}{l}\text { Item-total } \\
\text { correlation }\end{array}$ & $\begin{array}{c}\text { Cronbach } \\
\text { Alpha }\end{array}$ \\
\hline \multicolumn{7}{|c|}{ Pengalaman Merk (Brakus dkk., 2009) } \\
\hline \multicolumn{7}{|c|}{ Sensory } \\
\hline Sel & $\begin{array}{l}\text { Pada saat saya melihat merek ini } \\
\text { melalui indera penglihatan saya, } \\
\text { saya mendapatkan kesan yang } \\
\text { kuat mengenai merek dan } \\
\text { produknya }\end{array}$ & 0.781 & 1.899 & 63.298 & 0.506 & 0.709 \\
\hline $\mathrm{Se} 2$ & $\begin{array}{l}\text { Saya menemukan merek ini menarik } \\
\text { bagi indera saya secara } \\
\text { keseluruhan (penglihatan, } \\
\text { penciuman, perasa, peraba, } \\
\text { pendengaran) }\end{array}$ & 0.843 & & & 0.595 & \\
\hline $\mathrm{Se} 3$ & $\begin{array}{l}\text { Merek ini tidak menarik bagi indera } \\
\text { saya secara keseluruhan } \\
\text { (penglihatan, penciuman, perasa, } \\
\text { peraba, pendengaran) }\end{array}$ & 0.760 & & & 0.484 & \\
\hline \multicolumn{7}{|c|}{ Affective } \\
\hline Afel & $\begin{array}{l}\text { Perasaan yang berlebih-lebihan } \\
\text { (senang, gembira, riang) dari dalam } \\
\text { diri saya muncul ketika saya melihat } \\
\text { merek ini }\end{array}$ & 0.902 & 2.141 & 71.364 & 0.742 & 0.789 \\
\hline Afe2 & $\begin{array}{l}\text { Saya tidak memiliki ikatan emosi } \\
\text { yang kuat terhadap merek ini, bagi } \\
\text { saya merek ini hanyalah produk } \\
\text { biasa yang tidak memiliki arti bagi } \\
\text { diri saya }\end{array}$ & 0.781 & & & 0.547 & \\
\hline Afe3 & $\begin{array}{l}\text { Terdapat suatu ikatan emosi yang } \\
\text { kuat antara saya dengan merek ini, } \\
\text { bagi saya merek dari produk ini } \\
\text { sangat berarti dan tidak dapat } \\
\text { tergantikan dengan merek lainnya }\end{array}$ & 0.846 & & & 0.623 & \\
\hline \multicolumn{7}{|c|}{ Behavioral } \\
\hline Beh 1 & $\begin{array}{l}\text { Merek ini dapat mendorong saya } \\
\text { untuk terlibat seluruhnya secara fisik } \\
\text { (pada produk) dan perilaku ketika } \\
\text { menggunakan merek ini (perilaku } \\
\text { yang muncul pada saat } \\
\text { menggunakan produk) }\end{array}$ & 0.906 & 2.036 & 67.851 & 0.683 & 0.747 \\
\hline
\end{tabular}

\begin{tabular}{lllll}
\hline \hline Beh2 & \multicolumn{2}{l}{ Merek ini menghasilkan kesan yang } & 0.739 \\
mendalam pada diri saya saat & 0.932 & \\
\hline
\end{tabular}




\begin{tabular}{|c|c|c|c|c|c|c|}
\hline Beh3 & $\begin{array}{l}\text { menggunakannya dan tingkah laku } \\
\text { saya berubah karenanya } \\
\text { Merek ini tidak mendorong saya } \\
\text { untuk merubah perilaku saya dan } \\
\text { tidak selalu menyertai dalam setiap } \\
\text { aktivitas saya }\end{array}$ & 0.588 & & & 0.549 & \\
\hline \multicolumn{7}{|c|}{ Intellectual } \\
\hline Int1 & $\begin{array}{l}\text { Saya berpikir cukup lama ketika } \\
\text { saya melihat merek ini, banyak } \\
\text { pertimbangan yang muncul dalam } \\
\text { benak saya sebelum membelinya }\end{array}$ & 0.833 & 1.353 & 67.453 & 0.453 & 0.621 \\
\hline Int2 & $\begin{array}{l}\text { Ketika saya melihat merek ini, saya } \\
\text { tidak memiliki banyak pertimbangan } \\
\text { dan tidak membutuhkan waktu } \\
\text { berpikir yang lama untuk } \\
\text { membelinya }\end{array}$ & 0.885 & & & 0.453 & \\
\hline \multicolumn{7}{|c|}{ Keterikatan Emosional pada Merk (Thomson dkk. , 2005) } \\
\hline \multicolumn{7}{|c|}{ Affection } \\
\hline Affl & $\begin{array}{l}\text { Saya menyayangi Merek X dan saya } \\
\text { akan selalu menggunakannya }\end{array}$ & 0.771 & 2.976 & 74.408 & 0.623 & 0.884 \\
\hline Aff2 & $\begin{array}{l}\text { Saya dan Merek X dapat dikatakan } \\
\text { sebagai sepasang sahabat yang } \\
\text { selalu menemani saya pergi ke } \\
\text { berbagai tempat }\end{array}$ & 0.924 & & & 0.851 & \\
\hline Aff3 & $\begin{array}{l}\text { Saya dan Merek X dapat dikatakan } \\
\text { sebagai sepasang kekasih dan saya } \\
\text { tidak bisa jauh dari Merek X }\end{array}$ & 0.899 & & & 0.800 & \\
\hline Aff4 & $\begin{array}{l}\text { Merek X memberikan rasa damai } \\
\text { dalam hidup saya. Apabila Merek X } \\
\text { tidak bersama saya, saya merasa } \\
\text { gelisah }\end{array}$ & 0.849 & & & 0.721 & \\
\hline \multicolumn{7}{|c|}{ Passion } \\
\hline Pas 1 & $\begin{array}{l}\text { Merek } \quad X \quad \text { memberikan } \\
\text { gairah/semangat dalam hidup saya }\end{array}$ & 0.902 & 2.443 & 81.436 & 0.777 & 0.886 \\
\hline Pas2 & $\begin{array}{l}\text { Menggunakan Merek X memberikan } \\
\text { saya kegembiraan }\end{array}$ & 0.941 & & & 0.781 & \\
\hline Pas3 & $\begin{array}{l}\text { Merek X membuat saya terpesona } \\
\text { akan bentuknya dan segala hal } \\
\text { yang melekat padanya }\end{array}$ & 0.910 & & & 0.774 & \\
\hline \multicolumn{7}{|c|}{ Connection } \\
\hline Conl & $\begin{array}{l}\text { Saya dan Merek X selalu } \\
\text { tersambung, tidak pernah sekali pun } \\
\text { saya meninggalkannya }\end{array}$ & 0.870 & 2.228 & 76.252 & 0.702 & 0.844 \\
\hline Con2 & $\begin{array}{l}\text { Saya dan Merek X tidak dapat } \\
\text { dipisahkan }\end{array}$ & 0.913 & & & 0.743 & \\
\hline Con3 & $\begin{array}{l}\text { Saya sudah terikat oleh Merek X, } \\
\text { tidak ada yang dapat } \\
\text { menggantikan Merek X }\end{array}$ & 0.843 & & & 0.648 & \\
\hline \multicolumn{7}{|c|}{ Niat untuk Membeli Kembali (Wu dan Sukoco, 2010) } \\
\hline NMK1 & $\begin{array}{l}\text { Saya berniat untuk membeli merk ini } \\
\text { di kemudian hari }\end{array}$ & 0.891 & 1.918 & 63.929 & 0.678 & 0.715 \\
\hline NMK2 & $\begin{array}{l}\text { Saya akan dengan aktif mencari } \\
\text { informasi akan merk ini untuk } \\
\text { kemudian membelinya }\end{array}$ & 0.804 & & & 0.528 & \\
\hline NMK3 & $\begin{array}{l}\text { Saya berniat untuk membeli produk } \\
\text { lain dari merk ini }\end{array}$ & 0.690 & & & 0.515 & \\
\hline
\end{tabular}




\begin{tabular}{|c|c|c|c|c|c|c|}
\hline \multicolumn{7}{|c|}{ Keterlibatan pada Produk } \\
\hline $\mathrm{KpPl}$ & Tidak penting/penting & 0.827 & 4.077 & 67.942 & 0.741 & 0.903 \\
\hline KpP2 & $\begin{array}{l}\text { Tidak menjadi perhatian/menjadi } \\
\text { perhatian }\end{array}$ & 0.869 & & & 0.803 & \\
\hline KpP3 & Tidak cocok/cocok & 0.784 & & & 0.683 & \\
\hline KpP4 & Tidak berarti banyak/berarti banyak & 0.862 & & & 0.784 & \\
\hline KpP5 & Tidak bermanfaat/bermanfaat & 0.859 & & & 0.781 & \\
\hline KpP6 & $\begin{array}{l}\text { Dapat disepelekan/tidak dapat } \\
\text { disepelekan }\end{array}$ & 0.737 & & & 0.636 & \\
\hline
\end{tabular}

Guna menguji hipotesa, peneliti menggunakan structural equation modeling (SEM). Model yang diajukan mempunyai $\chi^{2}(\mathrm{df})=72,918(32), \mathrm{GFI}(\mathrm{RMR})=0,929(0,070)$, dan CFI (RMSEA) $=$ $0,957(0,085)$. Guna mengecek apakah model yang diajukan lebih baik dibandingkan model rival, peneliti membandingkan indeks fit (Bagozzi dan Yi, 1988). Model rival menyatakan bahwa pengalaman tidak berpengaruh terhadap keterlibatan emosional pada merk, dan kedua variabel tersebut berpengaruh langsung terhadap niat konsumen untuk membeli kembali. Hasilnya menunjukkan bahwa $\chi^{2}$ (df) $=233,579$ (32), GFI (RMR) = $0,842(0,283)$, dan CFI (RMSEA) $=0,788(0,184)$, sehingga model yang diajukan jelas lebih baik dibandingkan model rival. Berikut ini adalah model penelitian yang diajukan:

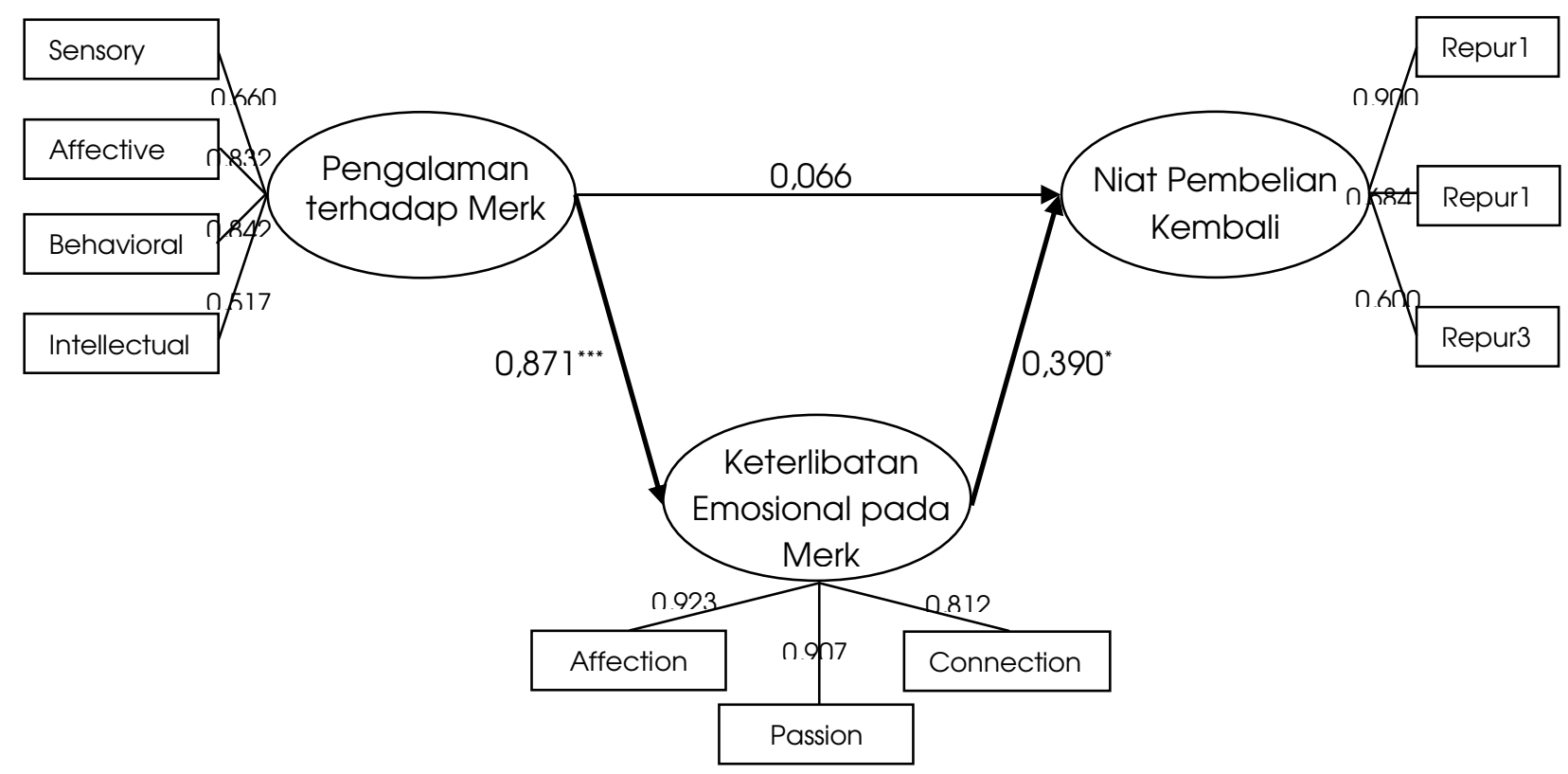

Gambar 1 - Model yang diajukan

Untuk menguji efek moderasi (Tabel 3), peneliti menggunakan regresi berjenjang mengingat variabel bebasnya merupakan variabel continuous. Menurut Aiken dan West (1991), penggunaan regresi berjenjang mampu mempertahankan sifat kontinyu dari sebuah variabel tanpa kehilangan informasi atau menurunkan kekuatan untuk mendeteksi efek moderasi. Mengingat variabel-variabel tersebut mempunyai multikolinearitas yang tinggi, maka peneliti menggunakan metode centering seperti yang disarankan oleh Frazier, Tix dan Barron (2004).

Hipotesa keempat menyatakan bahwa pengaruh positif pengalaman merk terhadap niat untuk membeli kembali akan semakin menguat bilamana konsumen mempunyai keterlibatan lebih tinggi terhadap produk. Hasil analisa menunjukkan bahwa terdapat pengaruh moderasi yang signifikan dari keterlibatan konsumen pada produk terhadap 
pengaruh pengalaman merk pada niat untuk membeli kembali $(\beta=0,163, p=0,023$ ), sehingga $\mathrm{H}_{4}$ dapat diterima. Hipotesa kelima menyatakan bahwa pengaruh positif keterlibatan emosional pada produk terhadap niat untuk membeli kembali akan semakin menguat bilamana konsumen mempunyai keterlibatan lebih tinggi terhadap produk. Hasil analisa menunjukkan bahwa terdapat pengaruh moderasi yang signifikan dari keterlibatan konsumen pada produk terhadap pengaruh pengalaman merk pada niat untuk membeli kembali ( $\beta=-0,168, p=0,062$ ), sehingga $\mathrm{H}_{4}$ tidak dapat diterima.

Tabel 2 - Regresi Linier Berjenjang

\begin{tabular}{|c|c|c|c|c|c|}
\hline \multirow[t]{2}{*}{ Variabel Independen } & \multicolumn{5}{|c|}{ Variabel Dependen: Niat untuk membeli kembali } \\
\hline & Model 0 & Model 1 & Model 2 & Model 3 & Model 4 \\
\hline \multicolumn{6}{|l|}{ Variabel Kontrol } \\
\hline Gender & $-0,039$ & $-0,038$ & $-0,029$ & $-0,018$ & $-0,013$ \\
\hline Pengeluaran bulanan & $0,131^{+}$ & 0,104 & 0,077 & $0,123^{+}$ & 0,093 \\
\hline Frekuensi penggunaan merk & 0,003 & 0,027 & 0,049 & 0,013 & 0,053 \\
\hline Lama penggunaan merk & $0,146^{+}$ & $0,262^{* * *}$ & $0,264^{* *}$ & $0,259^{* * *}$ & $0,246^{* * *}$ \\
\hline \multicolumn{6}{|l|}{ Efek Utama } \\
\hline Pengalaman pada merk (Exp) & & 0,124 & & $0,182^{+}$ & \\
\hline Keterlibatan emosional pada merk (Att) & & & $0,300^{* * *}$ & & $0,276^{* *}$ \\
\hline Keterlibatan pada produk (Inv) & & $0,330^{* * *}$ & $0,226^{*}$ & $0,260^{* *}$ & $0,205^{*}$ \\
\hline \multicolumn{6}{|l|}{ Efek Interaksi } \\
\hline Exp $x \ln v$ & & & & $-0,161^{*}$ & \\
\hline Att $x \ln v$ & & & & & $-0,168^{+}$ \\
\hline$R^{2}$ & 0,043 & 0,216 & 0,257 & 0,238 & 0,271 \\
\hline$\Delta \mathrm{R}^{2}$ & & 0,172 & 0,214 & 0,023 & 0,014 \\
\hline$\Delta \mathrm{F}$ & 1,968 & 19,016 & 24,943 & 5,158 & 3,359 \\
\hline Signifikansi & 0,101 & 0,000 & 0,000 & 0,024 & 0,069 \\
\hline
\end{tabular}

Catatan: + menunjukkan $\mathrm{p}<.05$, " menunjukkan $\mathrm{p}<.05,{ }^{* *}$ menunjukkan $\mathrm{p}<.01$, ${ }^{* * *}$ menunjukkan

$$
p<.001
$$

Menggunakan prosedur dari Aiken dan West (1991), peneliti menggambarkan efek moderasi tersebut (Gambar 2). Tingkat niat untuk membeli mempunyai nilai yang tidak jauh berbeda bilamana konsumen memiliki pengalaman pada merk dengan level yang tinggi $\left(\bar{X}_{\text {Tingsi }}=3,979, \bar{X}_{\text {Rendah }}=3,973\right.$ ). Bilamana mereka mempunyai keterlibatan yang tinggi terhadap produk namun mereka memiliki tingkat pengalaman yang rendah, tingkat niat untuk membeli sedikit lebih rendah ( $\bar{X}_{\text {Tingsi }}=3,758$ ). Tingkat pembelian kembali justru menurun drastis ketika konsumen memiliki keterlibatan yang rendah terhadap produk ( $\left.\bar{X}_{\text {Rendah }}=3,305\right)$. 


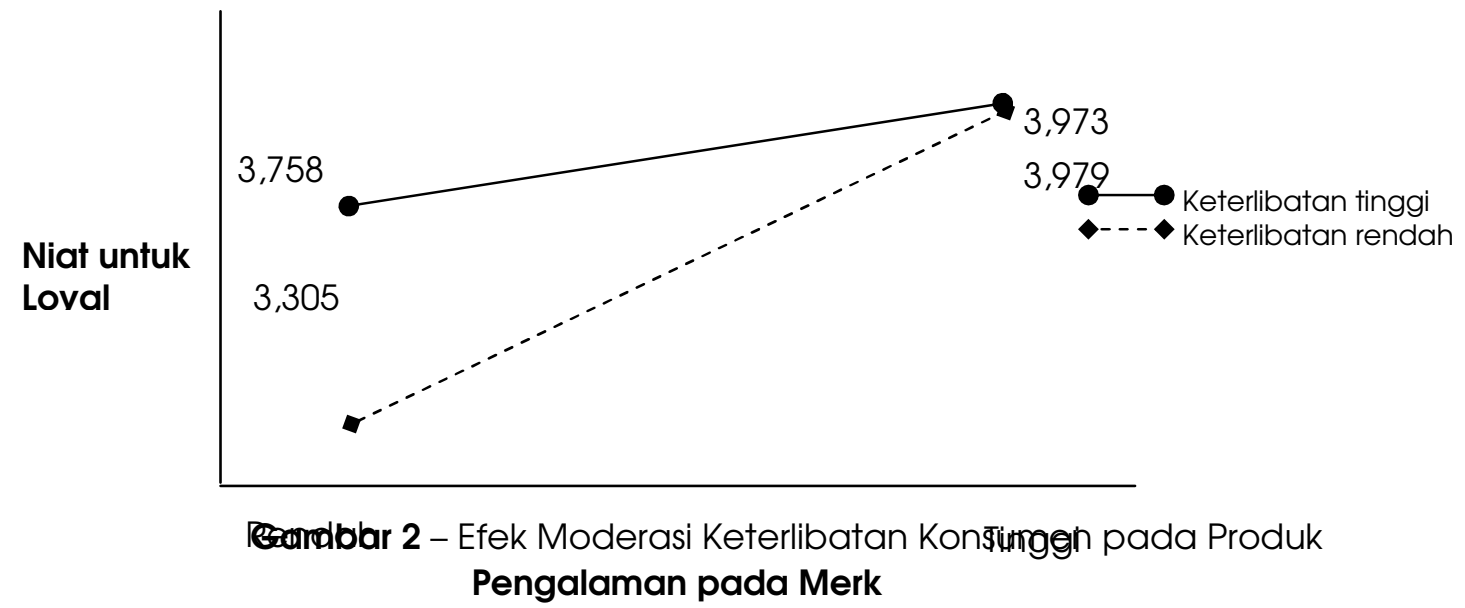

\section{SIMPULAN}

Beberapa kesimpulan yang dapat disajikan dalam penelitian ini adalah: Pertama, terdapat pengaruh yang signifikan dari pengalaman konsumen pada suatu merk dengan keterikatan emosional mereka. Hal ini konsisten dengan pendapat dari Belk (1988) bahwa keterikatan konsumen secara emosional akan dibangun dari waktu ke waktu ketika mereka berinteraksi dengan merk tersebut. Pengalaman yang ada jika diperkaya dengan interaksi yang intens tentunya akan mengembangkan keterikatan emosional yang dimiliki oleh konsumen (Baldwin dkk., 1996).

Kedua, tidak terdapat pengaruh langsung antara pengalaman merk dengan loyalitas konsumen. Hasil ini tidak konsisten dengan pendapat dari Oliver (1997) dan Reicheld (1996) maupun hasil penelitian yang dilakukan oleh Brakus dkk. (2009) pengalaman konsumen dengan suatu merk berpengaruh secara positif pada loyalitas konsumen. Hal ini mungkin disebabkan oleh desain penelitian ini yang menggunakan dua produk yang berbeda tingkat keterlibatan konsumennya, yakni HP dan snack. Alasan kedua mungkin disebabkan oleh penggunaan responden yang homogen, mahasiswa, yang tentunya memiliki banyak pertimbangan dan pilihan sebelum memutuskan untuk membeli lagi merk yang telah mereka gunakan. Keinginan untuk mencoba-coba guna memperkaya pengalaman mereka tentunya lebih mengedepan dibandingkan loyalitas yang mereka miliki.

Ketiga, penelitian ini menunjukkan bahwa keterikatan secara emosional mempengaruhi dampak positif terhadap loyalitas konsumen. Hasil ini konsisten dengan pendapat Bowlby (1980) yang menyatakan bahwa terikat secara emosional menjadikan seseorang berupaya untuk selalu dekat dengan suatu obyek (dalam hal ini merk). Hasil ini juga konsisten dengan pendapat Drigotas dan Rusbult (1992) maupun van Lange dkk. (1997) yang menyatakan konsumen yang terikat secara emosional akan memiliki komitmen yang tinggi yang diwujudkan dengan loyalitas terhadap suatu merk (Thomson dkk., 2005).

Keempat, penelitian ini menunjukkan bahwa fungsi moderasi dari keterlibatan produk hanya terdapat pada hubungan antara pengalaman merk dengan loyalitas. Hasil ini konsisten dengan argumen peneliti bahwa pengalaman konsumen pada suatu merk melibatkan semua aspek (baik subyektif dan perilaku) (Brakus dkk., 2009), dan dengan keterlibatan yang tinggi pada suatu produk akan memperkuat efek dari pengalaman merk terhadap niat konsumen untuk membeli kembali merk tersebut.

Berikut ini adalah beberapa implikasi bagi pemasar. Pertama, penelitian ini menunjukkan bahwa pengalaman terhadap suatu merk tidak berpengaruh langsung terhadap loyalitas yang dimiliki oleh konsumennya. Pengalaman tersebut perlu ditransformasi menjadi keterikatan secara emosional sebelum berpengaruh terhadap loyalitas konsumen. 
Merupakan tugas pemasar untuk mengubah pengalaman konsumen dengan suatu merk menjadi setingkat lebih lanjut berupa hubungan emosional. Bila secara emosional konsumen terikat, loyalitas terhadap merk tentunya menjadi akibat yang diharapkan. Kedua, penelitian ini juga menunjukkan bahwa tingkat keterlibatan yang tinggi terhadap produk dapat memperkuat pengaruh pengalaman pada loyalitas. Implikasinya, bagi pemasar dengan produk yang mempunyai keterlibatan rendah hendaknya meluncurkan program yang lebih kreatif agar tingkat pengalaman yang dimiliki konsumen dengan produk meningkat, misalnya dengan meluncurkan program testimoni kreatif berhadiah atau menciptakan ritual pengonsumsian produk yang unik (seperti yang dimiliki oleh Oreo - diputar, dijilat, dicelupin).

Selain implikasi bagi pemasar, penelitian ini juga memiliki implikasi akademis sebagai berikut: Pertama, penelitian ini menggabungkan konsep brand experience (Brakus dkk., 2009) dengan emotional attachment to brands (Thomson dkk., 2005). Penggabungan ini merupakan yang pertama dilakukan berdasarkan ide yang dilontarkan oleh Belk (1988) dan Baldwin (1996) yang menyatakan bahwa keterikatan emosional dipengaruhi oleh intensitas interaksi yang dilakukan oleh konsumen, yakni pengalaman, dengan suatu merk. Kedua, penelitian ini lebih komprehensif dibandingkan penelitian sebelumnya (Brakus dkk., 2009) karena menggunakan berbagai macam merk yang dibedakan berdasarkan tingkat keterlibatan yang berbeda terhadap suatu produk. Meskipun Brakus dkk. (2009) berpendapat bahwa pengalaman konsumen tidak ditentukan oleh keterlibatan yang mereka miliki terhadap suatu produk, namun penelitian ini menunjukkan bahwa tingkat keterlibatan konsumen mempunyai pengaruh moderasi.

Meskipun penelitian ini telah didesain sebaik mungkin, namun masih terdapat beberapa kelemahan. Pertama, penelitian ini hanya menggunakan mahasiswa di Departemen Manajemen, Universitas Airlangga. Meskipun internal validity dari hasil penelitian ini mampu tercukupi dengan baik, namun external validity patut dianalisis lebih lanjut. Untuk itu, penelitian selanjutnya perlu memperluas sampel responden yang akan digunakan sehingga external validity dapat ditingkatkan. Kedua, objek penelitian yang digunakan berdasarkan konsep product involvement (Park dan Mittal, 1985; Zaichkowsky, 1985). Penelitian selanjutnya dapat menggunakan konsep lainnya, misalnya produk utilitarian dan hedonic maupun konsep lainnya.

\section{DAFTAR PUSTAKA}

Aiken, L.S., dan S.G. West (1991). Multiple Regressions: Testing and Interpreting Interactions. Newbury Park, CA: Sage.

Ainsworth, M.D.S., M. Blehar, E. Waters, dan S. Wall (1978). Patterns of Attachment: A Psychological Study of the Strange Situation. Hillsdale, NJ: Lawrence Erlbaum Associates, Inc.

Anderson, J. C. dan D.W. Gerbing (1988). Structural Equation Modeling in Practice: A Review and Recommended Two-Step Approach. Psychological Bulletin, 103 (3): 41 1-423.

Arnould, E.J., L.L. Price, dan G. L. Zinkhan (2002). Consumers, 2ed. New York: McGrawHill/Richard D. Irwin.

Aron, A., dan L. Westbay (1996). Dimensions of the Prototype of Love. Journal of Personality and Social Psychology, 70: 535-551.

Bagozzi, R. dan Y. Yi (1998). On the Evaluation on Structural Equation Models. Journal of the Academy of Marketing Science, 16 (1): 74-94.

Baldwin, M.W., Keelan, J.P.R., Fehr, B., Enns, V., dan Koh-Rangarajoo, E. (1996). SocialCognitive Conceptualization of Attachment Working Models: Availability and Accessibility Effects. Journal of Personality and Social Psychology, 71: 94-109.

Beatty, S.E., dan S. Talpade. (1994). Adolescent Influence in Family Decision Making: A Replication with Extension. Journal of Consumer Research, 21 (September): 332-341. 
Belk, R. (1988). Possessions and the Extended Self. Journal of Consumer Research, 15: 139-168. Bowlby, J. (1979). The Making and Breaking of Affectional Bonds, London: Tavistock.

Bowlby, J. (1980). Loss: Sadness and depression. New York: Basic Books.

Brakus, J.J., B.H. Schmitt, dan Zarantonello, L. (2009). Brand Experience: What Is It? How Is It Measured? Does It Affect Loyalty? Journal of Marketing, 73: 52-68.

Brakus, J.J., B.H. Schmitt, and S. Zhang (2008). Experiential Attributes and Consumer Judgments, in Handbook on Brand and Experience Management, B.H. Schmitt and D. Rogers, eds. Northampton, MA: Edward Elgar.

Büschken, J. (2004). Higher Profits through Customer Lock-in. Mason, OH: Thomson.

Dick, A.S., dan K. Basu (1994). Customer Loyalty: Toward an Integrated Conceptual Framework. Journal of the Academy of Marketing Science, 22(2): 99-113.

Drigotas, S.M., dan C.E. Rusbult (1992). Should I Stay or Should I Go? A Dependence Model of Breakups. Journal of Personality and Social Psychology, 62: 62-87.

Feldman, J.M., dan J.G. Lynch Jr. (1988). Self Generated Validity and Other Effects of Measurement on Belief, Attitude, Intention and Behavior. Journal of Applied Psychology, 73(3): 421-35.

Frazier, P.A., A.P. Tix, dan K.E. Barron, K.E. (2004). Testing Moderator and Mediator Effects in Counseling Psychology Research. Journal of Counseling Psychology, 51: 115-134.

Grisaffe, D.B., dan H.P. Nguyen (2011). Antecedents of Emotional Attachment to Brands. Journal of Business Research, 64(10): 1052-1059.

Hazan, C. dan P.R. Shaver. (1994). Attachment as an Organizational Framework for Research on Close Relationships. Psychological Inquiry, 5: 1-22.

Keller, K. L. (1987). Memory Factors in Advertising: The Effects of Advertising Retrieval Cues on Brand Evaluations. Journal of Consumer Research, 14 (December): 316-33.

Kotler, P., dan K. L. Keller (2011). Marketing Management. Upper Saddle River, NJ: Prentice Hall.

Meyers-Levy, J. dan L.A. Peracchio (1995). How the Use of Color in Advertising Affects Attitudes: The Influence of Processing Motivation and Cognitive Demands. Journal of Consumer Research, 22 (September): 121-38.

Oliver, R.L. (1999). Whence Consumer Loyalty? Journal of Marketing, 63(4): 33-44.

Oliver, R.L. (1997). Satisfaction: A Behavioral Perspective on the Consumer, Boston: McGrawHill.

O'Brien, L., dan C. Jones (1995). Do Rewards Really Create Loyalty? Harvard Business Review, 73(3): 75-82.

Park, C.W., dan B. Mittal (1985). A Theory of Involvement in Consumer Behavior: Problems and Issues. Research in Consumer Behavior, 1, 201-232.

Podsakoff, P.M., dan D.W. Organ, (1986). Self-reports in Organizational Research: Problems and Prospects. Journal of Management, 12: 531-544.

Podsakoff, P.M., S.B. Mackenzie, J. Lee, dan N.P. Podsakoff (2003). Common Method Biases in Behavioral Research: A Critical Review of the Literature and Recommended Remedies. Journal of Applied Psychology, 88 (5): 879-903.

Reicheld, F.F. (1996). The Loyalty Effect: The Hidden Force Behind Growth, Profits, and Lasting Value, Boston: Harvard Business School Press.

Thomson, M., D.J. Maclnnis, dan C.W. Park (2005). The Ties That Bind: Measuring the Strength of Consumers' Emotional Attachments to Brands. Journal of Consumer Psychology, 15: 77-91.

Van Lange, P.A.M., C.E. Rusbult, S.M. Drigotas, X.B. Arriaga, B.S. Witcher, dan C.L. Cox (1997). Willingness to Sacrifice in Close Relationships. Journal of Personality and Social Psychology, 72: 1373-1396. 
Veryzer, R.W. dan J.W. Hutchinson (1998). The Influence of Unity and Prototypicality on Aesthetic Responses to New Product Designs. Journal of Consumer Research, 24(March): 374-94.

Weiss, R.S. (1988). Loss and recovery. Journal of Social Issues, 44: 37-52.

Wu, W-Y., dan Sukoco, B.M. (2010). Why Should I Share? Examining Consumers' Motives and Trust on Knowledge Sharing. Journal of Computer Information Systems, 50(4): 11-19.

Zaichkowsky, J.L. (1985). Measuring the Involvement Construct. Journal of Consumer Research, 12(3): 341-52. 